\title{
Integrality of care for hemodialysis patient in Brazil: an analysis of access to dental care
}

\author{
Integralidade do cuidado para pacientes brasileiros \\ em hemodiálise: análise do acesso odontológico
}

Bruna Mara Ruas (https://orcid.org/0000-0003-4310-8057) ${ }^{1}$

Lia Silva Castilho (http://orcid.org/0000-0001-9648-6815) ${ }^{2}$

Natália Cristina Ruy Carneiro (https://orcid.org/0000-0002-3028-7095) ${ }^{3}$

Natália Mendes de Matos Cardoso (https://orcid.org/0000-0001-5920-2166) ${ }^{3}$

Augusto Barbosa Reis (https://orcid.org/0000-0002-2797-2219) ${ }^{4}$

Maria Elisa Sousa e Silva (http://orcid.org/0000-0001-5803-7568) ${ }^{2}$

Ana Cristina Borges-Oliveira (https://orcid.org/0000-0003-3364-4024) ${ }^{1}$
${ }^{1}$ Departamento de Odontologia Social e Preventiva, Faculdade de Odontologia, Universidade Federal de Minas Gerais (UFMG). Av. Presidente Antônio Carlos 6627, Pampulha. 31270-901 Belo Horizonte MG Brasil. brunamara@gmail.com

${ }^{2}$ Departamento de Odontologia Restauradora, Faculdade de Odontologia, UFMG. Belo Horizonte MG Brasil.

${ }^{3}$ Departamento de Odontopediatria e Ortodontia, Faculdade de Odontologia, UFMG. Belo Horizonte MG Brasil.

${ }^{4}$ Departamento de

Nefrologia e Urologia, Faculdade de Odontologia, UFMG. Belo Horizonte MG Brasil.

\begin{abstract}
The present study aimed to analyze factors associated with access of dental care services by Brazilian hemodialysis patients. A cross-sectional study was carried out with 467 hemodialysis patients aging from 19 to 90 years in two renal therapy centers located in the cities of Contagem and Belo Horizonte, Southeastern Brazil. Data were collected through an oral clinical examination of the patients and the application of a structured questionnaire. The dependent variable was the access to dental care, measured by the question "Have you consulted with a dentist in last six months?". The mean age of participants was 49.9 years. The average number of teeth present in the mouth was 19.3. An average of 1.5 teeth with dental caries cavities lesion was diagnosed among hemodialysis patients. One-third of the sample had gone to the dentist in the last six months (27.8\%). The access to dental care was associated with formal education $(O R=1.5$ [1.1-2.4]), professional advising to consult with a dentist $(O R=2.1$ [1.2-3.8]) and prevalence of dental caries (OR $=$ 2.1 [1.3-3.2]). Hemodialysis patients with eight or more years of formal education, who received professional advising to consult with a dentist and without dental caries cavities had higher chances obtaining access to dental care.

Key words Hemodialysis, Chronic kidney disease, Renal Dialysis, Dental Access, Dental care
\end{abstract}

Resumo Este estudo objetivou analisar os fatores associados ao uso de serviços odontológicos por pacientes em hemodiálise. Foi realizado um estudo transversal com 467 pacientes em hemodiálise, na faixa etária de 19 a 90 anos, de Contagem e Belo Horizonte, região Sudeste do Brasil. Os dados foram coletados por meio de exame clínico bucal dos participantes e da aplicação de um questionário estruturado. A variável dependente foi o acesso odontológico, mensurado pela pergunta "Você foi ao dentista nos últimos seis meses?". A média de idade dos participantes foi de 49,9 anos. A média de dentes presentes na boca foi de 19,3. Uma média de 1,5 dentes com lesão de cárie cavitada foi diagnosticada entre os pacientes em hemodiálise. Um terço da amostra afirmou ter ido ao dentista nos últimos seis meses (27,8\%). O acesso odontológico dos pacientes em hemodiálise foi associado à escolaridade $(O R=1,5[1,1-2,4])$, orientação profissional para ir ao dentista $(O R=2,1[1,2-$ $3,8])$ e prevalência de cárie dentária $(O R=2,1$ [1,3-3,2]). Os pacientes em hemodiálise com oito anos ou mais de escolaridade, que receberam orientação profissional para ir ao dentista e sem cárie dentária apresentaram maior chance de terem acesso odontológico.

Palavras-chave Hemodiálise, Doença Crônica Renal, Diálise Renal, Acesso odontológico, Cuidado Odontológico 


\section{Introduction}

The chronic kidney disease (CKD), also known as chronic renal failure, is characterized by the slow and progressive loss of renal functions. It is irreversible and demands a significant amount of therapeutic options that consist of artificial blood clearance: peritoneal dialysis, hemodialysis and kidney transplantation ${ }^{1-4}$. This disease presents a high mortality index, being a public health problem ${ }^{2-4}$. In Brazil, the rates of CKD have considerably increased ${ }^{3,5}$.

Generally, individuals with CKD face many health problems and have low immunity. This happens, especially with those individuals who are on immunosuppressive therapy before kidney transplantation. A notable number of individuals with CKD present high prevalence of periodontal diseases and dental caries. This may be explain by the fact that they are immunosuppressed, and also, frequently associated with deficient oral hygiene, presence of dental plaque and dental calculus ${ }^{1,4-8}$.

CKD individuals are identified as a group with several oral disorders, and have a high demand for dental care. For different reasons, these individuals frequently have limited access to dental care services ${ }^{9,10}$.

There are still important geographic and social inequalities regarding access to dental care in both public and private services ${ }^{10}$. Improvements on the accessibility to dental care services for vulnerable populations had been proposed, and some progress had already been observed ${ }^{9,10}$. As an example of interventions that may contribute to forwarding access to dental care services is the development of individual and public strategies for people with CKD, addressing the importance of multidisciplinary health care and, within this context, issues related to oral health care. Such initiatives positively reflect on the health and well -being of the patient ${ }^{2,8,11}$.

Therefore, this study aimed to analyze factors associated with access of dental care services for patients undergoing hemodialysis therapy in Brazil.

\section{Methods}

A cross-sectional study was conducted with patients undergoing hemodialysis in two philanthropic renal therapy centers located in the cities of Contagem and Belo Horizonte, both in Southeastern Brazil. The total number of individuals undergoing hemodialysis therapy in both centers during data collection was 764 patients.

Patients who were present at the centers on the day of data collection, answered the questionnaire, agreed with the oral clinical examination and signed the informed consent form, were included in the study. The study was approved by the Human Research Ethics Committee of the Federal University of Minas Gerais, Brazil. Data were collected through the application of a structured questionnaire and oral clinical examination while hemodialysis was being performed for the patients.

The questionnaire contained questions related to the patient's sociodemographic characteristics, as well as behavior habits, dental and medical history. Ethnicity was registered according to criteria established by the Brazilian Institute of Geography and Statistics ${ }^{12}$. Formal education was measured by the number of years the patient attended formal education institutions, as school and college.

The questionnaire was based on previous studies $^{1,2,5,13,14}$ and was submitted to the evaluation of two researchers in Dentistry and Public Health. Testing and re-testing of the questionnaire was performed to evaluate its internal validity. To do so, the questionnaire was applied twice to 13 hemodialysis patients at the renal therapy center of Belo Horizonte, with a 7-day interval between each application. Kappa and weighted kappa values ranging from 0.72 and 1.00 were obtained, ensuring the internal validity of the instrument.

The questionnaire was carried as an interview with each patient during the hemodialysis therapy session. After the interview ended, the oral clinical examination was performed using a sterilized mouth mirror (Prisma, São Paulo, SP, Brazil) and a community periodontal index probe (Golgran ${ }^{\circledR}$, São Paulo, SP, Brazil), under natural light. Data on the prevalence of dental caries and gingivitis, as well as the presence of dental calculus and oral mucosa disorders were recorded based on the criteria adopted by the World Health Organization ${ }^{15}$. Gingivitis was recorded as present or absent based on abnormal gingival contour and color, and presence of visible dental calculus (supragingival calculus) was recorded for each tooth as present or absent. No invasive clinical examination was performed on the patients. That is, no clinical instrument was used to identify the presence of gingivitis and dental calculus. Therefore, the prophylactic use of antibiotics was not necessary.

After clinical oral examination, individuals identified with some need for dental treatment were referred to the Faculty of Dentistry of UFMG. 
Prior to the main study, intra and inter-examiner calibration was carried. The intra and inter -examiner calibration first included a theoretical discussion about the clinical criteria used for the classification of the oral conditions of interest. It was defined with training through slides and clinical examinations on the participants ${ }^{16,17}$. Second, a practical calibration was carried out with the same thirteen patients who took part of the internal validation of the questionnaire. These patients were examined and reexamined after a 7 -day interval. Kappa values obtained for the oral conditions ranged from 0.82 to 0.97 and were considered good for the calibration step ${ }^{17}$. These patients were not included in the main study.

After the test/re-test and calibration steps, a pilot study was carried out for methodological and logistical analyses. The sample of the pilot study included 30 patients from the therapy center in Contagem and 30 patients from the therapy center of Belo Horizonte. Since there were no methodological changes in the study after the pilot, these participants were included in the main study.

Data analysis was carried out using the software Statistical Package for the Social Sciences (SPSS for Windows, version 21.0, SPSS Inc., Chicago, Ill). Univariate, bivariate (chi-square, $\mathrm{p}<0.05$ ) and multivariate analyzes (logistic regression) were performed. The dependent variable was the access to dental care, measured by the question "Have you consulted with a dentist in last six months?". The independent variables were: city where the therapy center is located, patient's home city, sex, skin color, age, time undergoing hemodialysis therapy, professional advising to consult with a dentist, formal education, number of teeth present in the mouth, prevalence of dental caries, gingivitis and dental calculus. Independent variables were included into the multivariate model in accordance with their statistical significance $(\mathrm{p}<0.25$, backward stepwise selection).

\section{Results}

A total of 467 patients were included in the main study. Among 764 patients registered at both renal therapy centers by the moment of the data collection, 111 (14.52\%) were not included into the main study due to the following reasons: absence on the day of data collection, refusal in participating, death, patients who were too weakened and patients who participated in the calibration and testing-retesting steps. 183 edentulous patients $(23.9 \%)$ and 3 teenagers $(0.39 \%)$ were also excluded.

The age of the participants ranged from 19 to 90 years, with an average of 49.9 years $( \pm 13.7)$ and median age of 51.0 years. An average number of teeth present in the mouth was $19.3( \pm 8.7)$ and median of 21.0. An average of $1.5( \pm 2.2)$ teeth with dental caries was diagnosed among the hemodialysis patients, the median being of 1.0.

Table 1 describes sociodemographic characteristics of the participants. The majority of participants reported not having consulted with a dentist in the last six months $(72.2 \% / \mathrm{n}=337)$ and not having received professional advising to consult with a dentist $(87.4 \% / \mathrm{n}=408)$.

Table 2 summarizes a statistically significant association between access to dental care and the variables: sex, formal education, professional advising to consult with a dentist and dental caries prevalence $(\mathrm{p}<0.05)$.

Multiple logistic regression analysis revealed participants with eight or more years of formal education (OR $=1.69 ; 95 \%$ IC: $1.11-2.57$ ) had a 1.5 times higher chance of belonging to the group of patients under hemodialysis therapy who reported having consulted with a dentist in the last six months (Table 3). Patients who reported having received professional advising to consult with a dentist $(\mathrm{OR}=2.16$; 95\% IC: 1.21 $3.86)$, as well as patients diagnosed without dental caries (OR $=2.09$; 95\% IC: $1.36-3.20)$ showed about twice the chances of having consulted with a dentist in the last 6 months.

\section{Discussion}

Most of the participants of this study reported not having consulted with a dentist in the last 6 months. Although literature demonstrates the demand for dental care is high among individuals with $\mathrm{CKD}^{1,4,8}$, these results suggest this portion of the population is not receiving dental care.

When discussing access to dental care, it's important to emphasize there are inequalities when it comes to the perception of dental treatment needs, as well as access to such treatments, most importantly to the more vulnerable segments of the population ${ }^{18}$. Socioeconomic questions, such as increase of a person's income, are not enough to solve all of the problems. There are still important questions, such as beliefs, behavior and life conditions, which deserve further resear$\mathrm{ch}^{8-10,18-20}$. Based on this information, some con- 
Table 1. Distribution of the hemodialysis patients according to sociodemographic, medical and dental variables $(n=467)$.

\begin{tabular}{|c|c|c|}
\hline Variable & $\begin{array}{l}\text { Absolute } \\
\text { frequency } \\
(\mathbf{n})\end{array}$ & $\begin{array}{c}\text { Relative } \\
\text { frequency } \\
(\%)\end{array}$ \\
\hline \multicolumn{3}{|l|}{ Age (years) } \\
\hline $19-51$ & 248 & 53.1 \\
\hline $52-90$ & 219 & 46.9 \\
\hline \multicolumn{3}{|l|}{ Sex } \\
\hline Female & 196 & 42.0 \\
\hline Male & 271 & 58.0 \\
\hline \multicolumn{3}{|l|}{ Skin color } \\
\hline White & 81 & 17.3 \\
\hline Black/Brown & 386 & 82.7 \\
\hline \multicolumn{3}{|l|}{ Economic status } \\
\hline Most favored & 82 & 17.6 \\
\hline Favored & 321 & 68.7 \\
\hline Less favored & 64 & 13.7 \\
\hline \multicolumn{3}{|l|}{$\begin{array}{l}\text { Formal education (years } \\
\text { study) }\end{array}$} \\
\hline$\geq 8$ & 160 & 34.3 \\
\hline$<8$ & 307 & 65.7 \\
\hline \multicolumn{3}{|l|}{$\begin{array}{l}\text { City where the } \\
\text { hemodialysis center is } \\
\text { located }\end{array}$} \\
\hline Belo Horizonte & 245 & 52.5 \\
\hline Contagem & 222 & 47.5 \\
\hline \multicolumn{3}{|l|}{ Home City } \\
\hline Belo Horizonte & 174 & 37.3 \\
\hline Metropolitan region & 293 & 62.7 \\
\hline \multicolumn{3}{|l|}{$\begin{array}{l}\text { Time undergoing } \\
\text { hemodialysis therapy }\end{array}$} \\
\hline$<5$ years & 308 & 66,0 \\
\hline$\geq 5$ years & 159 & 34,0 \\
\hline \multicolumn{3}{|l|}{$\begin{array}{l}\text { Having consulted with } \\
\text { a dentist in the last six } \\
\text { months }\end{array}$} \\
\hline No & 337 & 72,2 \\
\hline Yes & 130 & 27,8 \\
\hline \multicolumn{3}{|l|}{$\begin{array}{l}\text { Professional advising to } \\
\text { consult with a dentist }\end{array}$} \\
\hline No & 408 & 87.4 \\
\hline Yes & 59 & 12.6 \\
\hline \multicolumn{3}{|l|}{$\begin{array}{l}\text { Numbers of teeth with } \\
\text { dental cavitary caries }\end{array}$} \\
\hline Zero & 207 & 44.3 \\
\hline One to 20 & 260 & 55.7 \\
\hline \multicolumn{3}{|l|}{ Gingivitis } \\
\hline Absent & 216 & 46.3 \\
\hline Present & 251 & 53.7 \\
\hline \multicolumn{3}{|l|}{ Dental calculus } \\
\hline Absent & 223 & 47.8 .0 \\
\hline Present & 244 & 52.2 \\
\hline
\end{tabular}

siderations regarding the lack of dental care are further discussed below.

The results revealed the participants who had eight or more years of formal education presented a 1.5 higher chance of belonging to the group of patients who reported having consulted with a dentist in the last six months. Patients who had less formal education are normally associated with a lower income, which probably hinders access to dental care services since less financial resources are available for dental treatment and periodic consultations with dentists. Literature highlights that socioeconomic conditions are directly related to the frequency of recent consultations with dentists ${ }^{18-22}$.

The use of public services is associated with a lower family income. As such income is divided among the members of the family, more individuals belonging to a family group increases the chances of using public health services, yet, associated with the need of treatment presented by the individual and the organization of oral health care in the city as a context factor ${ }^{20}$.

Most of the patients under renal therapy have a low income, which hinders their access to dental care services. This happens in many cases. The public health service is not capable to providing places for more complex restoration and rehabilitation treatments ${ }^{9,10}$.

As inequalities regarding access and utilization of health services have been identified, it is important to elaborate strategies and actions that improve access possible for people with lower income to public dental care services. Although innovative initiatives have been proposed, the inequalities do not present a decreasing rate over time 19,21,22 $^{\text {. }}$

Receiving professional advising to consult with a dentist was another factor statistically associated to dental care for CKD patients to look for dental services. The results show that professional advising to consult with a dentist doubled the chances of patients to have consulted with a dentist in the last six months, highlightening the importance of a multidisciplinary team to assist CKD patients when it comes to oral hygiene. It is essential to inform the dialysis team about the importance of good oral health, as well as stimulating the team to lead patients to the proper dental care assistance. Jain et al. ${ }^{11}$ note that advising can help motivate hemodialysis patients and explain to them the importance of a good oral health. Besides, many CKD patients need kidney transplantation and one criterion used to perform kidney transplantation is the condition of oral health ${ }^{8,23}$. 
Table 2. Absolute and relative frequency of the hemodialysis patients' socio demographic, medical and dental variables according to the access to dental care $(n=467)$.

\begin{tabular}{|c|c|c|c|c|c|}
\hline \multirow{2}{*}{\multicolumn{2}{|c|}{ Individual variables }} & \multicolumn{3}{|c|}{ Dental care (<6 months) } & \multirow{3}{*}{$\begin{array}{c}\begin{array}{c}\mathbf{P} \\
\text { value }^{\times}\end{array} \\
0,223\end{array}$} \\
\hline & & \multirow{2}{*}{$\begin{array}{c}\text { Present } \\
\text { n (\%) }\end{array}$} & \multirow{2}{*}{$\begin{array}{c}\begin{array}{c}\text { Absent } \\
\text { n (\%) }\end{array} \\
174(70.2)\end{array}$} & \multirow{2}{*}{$\begin{array}{c}\begin{array}{c}\text { Total } \\
\mathbf{n}(\mathbf{1 0 0 \%})\end{array} \\
248\end{array}$} & \\
\hline Age (years) & $19-51$ & & & & \\
\hline & $52-90$ & $56(25.6)$ & $163(74.4)$ & 219 & \\
\hline \multirow[t]{2}{*}{ Sex } & Female & $64(32.7)$ & $132(67.3)$ & 196 & 0,048 \\
\hline & Male & $66(24.4)$ & $205(75.6)$ & 271 & \\
\hline \multirow[t]{2}{*}{ Skin Color } & Write & $25(30.9)$ & $56(69.1)$ & 81 & 0.504 \\
\hline & Black/Yellow & $105(27.2)$ & $281(72.8)$ & 386 & \\
\hline \multirow[t]{3}{*}{ Economic Position } & Most favored & $29(35.4)$ & $53(64.6)$ & 82 & 0.028 \\
\hline & Favored & $91(28.3)$ & $230(71.7)$ & 321 & \\
\hline & Less favored & $12(18.8)$ & $52(81.3)$ & 64 & \\
\hline \multirow{2}{*}{$\begin{array}{l}\text { Formal education } \\
\text { (years study) }\end{array}$} & $\geq 8$ & $56(35.0)$ & $104(65.0)$ & 160 & 0.013 \\
\hline & $<8$ & $74(24.1)$ & $233(75.9)$ & 307 & \\
\hline \multirow{2}{*}{$\begin{array}{l}\text { City where the hemodialysis } \\
\text { center is located }\end{array}$} & Belo Horizonte & $67(27.3)$ & $178(72.7)$ & 245 & 0.804 \\
\hline & Contagem & $63(28.4)$ & $159(71.6)$ & 222 & \\
\hline \multirow[t]{2}{*}{ Home City } & Belo Horizonte & $49(28.2)$ & $125(71.8)$ & 174 & 0.901 \\
\hline & Metropolitan region & $81(27.6)$ & $212(72.4)$ & 293 & \\
\hline \multirow[t]{2}{*}{ Hemodialysis treatment time } & $<5$ & $87(28.2)$ & $221(71.8)$ & 308 & 0.783 \\
\hline & $\geq 5$ or more & $43(27.0)$ & $116(73.0)$ & 159 & \\
\hline \multirow{2}{*}{$\begin{array}{l}\text { Professional advising to } \\
\text { consult with a dentist }\end{array}$} & Yes & $26(44.1)$ & $33(55.9)$ & 59 & 0.003 \\
\hline & No & $104(25.5)$ & $304(74.5)$ & 408 & \\
\hline \multirow{2}{*}{$\begin{array}{l}\text { Numbers of teeth with dental } \\
\text { cavitary caries }\end{array}$} & Zero & $77(37.2)$ & $130(62,8)$ & 207 & $<0.001$ \\
\hline & One to 20 & $53(20.4)$ & $207(79.6)$ & 260 & \\
\hline \multirow[t]{2}{*}{ Gingivitis } & Absent & $81(37.5)$ & $135(62.5)$ & 216 & $<0.001$ \\
\hline & Present & $51(20.3)$ & $200(79.7)$ & 251 & \\
\hline \multirow[t]{2}{*}{ Dental calculus } & Absent & $83(37.2)$ & $140(62.8)$ & 223 & $<0.001$ \\
\hline & Present & $49(20.1)$ & $195(79.9)$ & 244 & \\
\hline
\end{tabular}

${ }^{\star} \mathrm{X}^{2}$ Test (significance level of 5\%); value in bold: statistical significance $(<0.05)$.

Table 3. Multivariate model of logistical regression to explain the access to dental care in patients under hemodialysis therapy $(\mathrm{n}=467)$.

\begin{tabular}{lcc}
\hline \multicolumn{1}{c}{ Independents variables (Categories) } & OR (CI 95\%) Crude & OR (CI 95\%)Adjusted \\
\hline Formal Education $(\geq 8$ years) & $1.69(1.11-2.57)$ & $1.88(1.18-2.98)$ \\
Professional advising to consult with a dentist (yes) & $2.30(1.31-4.03)$ & $1.98(1.10-3.55)$ \\
Numbers of teeth with dental cavitary caries (Zero) & $2.31(1.53-3.49)$ & $1.92(1.09-3.39)$ \\
\hline
\end{tabular}

${ }^{*}$ Adjusted for control variable (age); OR: Odds Ratio; CI 95\%: Confidence interval.

Literature also highlights individuals undergoing renal dialysis present higher levels of anxiety, stress and depression ${ }^{2,11,13,23,24}$. According to the authors, under such conditions, these individuals tend to disregard their oral health care, what can often lead to tooth loss.

However, when the patients are advised by one of the professionals who are assisting them with the CKD treatments about the importance of seeking dental care services, the patients show a tendency of following the advice. Hence, having access to routine care based on the principle of integrality is extremely important for this part of the population. Mattos ${ }^{25}$ said that, within the integrality context, health professionals should adopt an attitude that identifies the needs of pre- 
vention and assistance based on technical knowledge, selecting the interventions provided in the context of each meeting.

"The dispute between minimum and basics is all about the integrality of health care"26.

Integrality starts with the organization of work processes in the basic attention, with a multidisciplinary professional assistance for the patient and through directives such as reception, linking and team accountability for the integral health care. For this reason, oral health should always be embedded in this context $\mathrm{t}^{25,26}$.

Concerning integrality as health practice, the Lines of Care and of Networks of Health Attention are currently considered the most recent technological proposition in the search for integrality by the Brazilian Health System (Sistema Único de Saúde - SUS). While the Networks of Health Attention consist in organizational arrangements of action and health services, the Lines of Care configure the expression of the assistance flows ${ }^{26}$. CKD patients might be the scope of a Care Line, since an organized Integral Care Line allows the health service to work focused on the user's needs instead focusing on the services offered, which normally limits access to health care ${ }^{24,27-29}$.

Martins et al. ${ }^{27}$ point out the existing difficulty in the relationship between primary and secondary attention of dental specialties in some Brazilian regions, with great limitations to the access for specialties centers, which represents a rupture on the principle of integrality in the organizational sense of the service.

The data showed that CKD patients identified without dental caries presented twice the chances of having consulted with a dentist in the last six months. Most likely, this is a consequence of these patients who had consulted with a dentist having received preventive and healing actions. According to several authors, increasing access to dental care cautiously reduces the prevalence and the severity of dental caries ${ }^{28,29}$.

Regarding dental caries, there is no consensus in the literature about the prevalence of such disease in CKD patients. Some authors report patients with CKD present lower indexes of dental caries when compared to the portion of population without the disease $e^{1,11,30-33}$.

Although literature brings up evidences of a statistical association between oral health conditions of CKD patients and time under hemo- dialysis therapy ${ }^{1,11,30-33}$, such association was not verified by this study. Such divergence of results might indicate a possible bias in the participants' memories, as well as the need of a cohort study that makes possible to clarify, with more details, a possible relationship of temporality, corroborating the hypothesis that a longer time under hemodialysis therapy is associated with worse oral health conditions. Dumitrescu et al. ${ }^{13}$ carried out a study in Romania with 161 (one hundred sixty-one) adults undergoing hemodialysis and found that dental care was not related to time those patients were under hemodialysis therapy. According to the authors, those results are conflicting and it is not possible to infer whether there is a higher prevalence of oral disorders and severity in the population at the final stage of CKD.

Potential confusion factors this population include: high prevalence of diabetes mellitus, smoking, age, medical control level over the disease and its complications, potential ethnic or demographic variables that influence access to oral health care, as well as selection bias.

Among the limitations of this study, the use of a cross-sectional design does not allow analysis of temporal or causal relationships among the variables. By obtaining information through the use of a questionnaire, it is important to consider a possible memory bias, which may have affected responses to questions about time under hemodialysis therapy and last consultation with a dentist. It was a convenience sample given the difficulty of selecting participants. Also, since it was a non-probabilistic sample, the external validity of the results is not viable. Moreover, the absence of a control group makes it difficult to extrapolate the results of this study.

The high rate of dental assistance denied to CKD patients when it comes to the access of dental care for this portion of the population should be highlighted, what often happens due to the systemic condition of the patients and to the demanding nursing for CKD patients. Many dentists do not feel prepared, safe and trained to treat a CKD patient ${ }^{11,14,24,33}$. Such a situation corroborates the need of a work practice based on the integrality of health care. The knowledge exchange and the experience of the professionals are both fundamental to assist the patients with $\mathrm{CKD}$ and other diseases. 


\section{Collaborations}

BM Ruas participated in the study development, data collection and writing of the manuscript. LS Castilho, NCR Carneiro, NMM Cardoso and $\mathrm{AB}$ Reis participated in the writing and critical analysis of the manuscript. MSE Silva participated in the study development, data collection, as well as the critical analysis of the manuscript. AC Borges-Oliveira participated in the development of the study, analysis and interpretation of data, writing and critical analysis of the manuscript.

\section{References}

1. Bayraktar G, Kurtulus I, Duraduryan A, Cintan S, Kazancioglu R, Yildiz A, Bural C, Bozfakioglu S, Besler M, Trablus S. Dental and periodontal findings in hemodialysis patients. Oral Dis 2007; 13(4):393-397.

2. Ruokonen H, Nylund K, Furuholm J, Meurman JH, Sorsa T, Kotaniemi K, Ortiz F, Heikkinen AM. Oral health and mortality in patients with chronic kidney Disease. J Periodontol 2017; 88(1):26-33.

3. Levey AS, Coresh J, Balk E, Kausz AT, Levin A, Steffes MW, Hogg RJ, Perrone RD, Lau J, Eknoyan G. National Kidney Foundation practice guidelines for chronic kidney disease: evaluation, classification, and stratification. Ann Intern Med 2003; 139(2):137-147.

4. Bots CP, Poorterman JHG, Brand HS, Kalsbeek H, Van Amerongen BM, Veerman ECI, Nieuw Amerongen AV. The oral health status of dentate patients with chronic renal failure undergoing dialysis therapy. Oral Dis 2006; 12(2):176-180.

5. Cunha FL, Tagliaferro EP, Pereira AC, Meneghim MC, Hebling E. Oral health of a Brazilian population on renal dialysis. Spec Care Dentist 2007; 27(6):227-231.

6. Akar H, Akar GC, Carrero JJ, Stenvinkel P, Lindholm B. Systemic consequences of poor oral health in chronic kidney disease patients. Clin J Am Soc Nephrol 2011; 6(1):218-226.

7. Dirschnabel AJ, de Souza Martins A, Dantas SAG, de Oliveira Ribas M, Grégio AMT, Alanis LR, Ignacio AS, Trevilatto PC, Casagrande RW, Lima AA, Machado MÂ. Clinical oral findings in dialysis and kidney-transplant patients. Quintessence Int 2011; 42(2):127-133.

8. Schmalz G, Kollmar O, Vasko R, Müller GA, Haak R, Ziebolz D. Oral health-related quality of life in patients on chronic haemodialysis and after kidney transplantation. Oral Dis 2016; 22(7):665-672.

9. Bonito A. Dental care considerations for vulnerable populations. Spec care Dentist 2001; 22(Supl. 3):5S-10S.

10. Truong A, Higgs P, Cogger S, Dietze P. Further research required to determine unique factors associated with dental care access among deprived populations. Public Health 2014; 128(12):1131-1133.

11. Jain S, Singla A, Basavaraj P, Singh S, Singh K, Kundu H. Underlying kidney disease and duration of hemodialysis: an assessment of its effect on oral health. $J$ Clin Diagn Res 2014; 8(5):ZC65.

12. Instituto Brasileiro de Geografia e Estatística (IBGE). Características étnico-raciais da população: um estudo das categorias de classificação de cor ou raça 2008 [Internet]. Rio de Janeiro: IBGE; 2011. [cited 2016 Nov 12]. Available from: http://biblioteca.ibge.gov.br/visualizacao/livros/liv49891.pdf

13. Dumitrescu AL, Gârneapã L, Guzun O. Anxiety, stress, depression, oral health status and behaviours in Romanian hemodialysis patients. Rom J Intern Med 2009; 47(2):161-168.

14. Chen LP, CK Chiang, Peng YS, Hsu SP, Lin CY, Lai CF, Hung KY. Relationship between periodontal disease and mortality in patients treated with maintenance hemodialysis. Am J Kidney Dis 2011; 57(2):276-282.

15. World Health Organization (WHO). Oral Health Surveys [Internet]. $5^{\text {th }}$ ed. Geneva: WHO; 2013. [cited 2016 Nov 11]. Available from: http://www.who.int/ oral_health/publications/9789241548649/en/ 
16. Kirkwood BR, Stern J. Essential Medical Statistics. $2^{\text {nd }}$ ed. London, England: Blackwell; 2003.

17. Rigby AS. Statistical methods in epidemiology. v. Towards an understanding of the kappa coefficient. Disabil Rehabil 2000; 22(8):339-344.

18. Pinheiro RS, Viacava F, Travassos C, Brito AS. Gênero, morbidade, acesso e utilização de serviços de saúde no Brasil. Cien Saude Colet 2002; 7(4):687-707.

19. Baldani MH, Antunes JLF. Inequalities in access and utilization of dental services: a cross-sectional study in an area covered by the Family Health Strategy. Cad Saude Publica 2011; 27(Supl. 2):S272-S283.

20. Pinto RS, Roncalli AG, Abreu MH, Vargas AM. Use of public oral health services by the adult population: a multilevel analysis. PloS One 2016; 11(1):e0145149.

21. Monteiro CN, Beenackers MlA, Goldbaum M, Barros MBA, Gianini RJ, Cesar CLG, Mackenbach JP. Socioeconomic inequalities in dental health services in Sao Paulo, Brazil, 2003-2008. BMC Health Serv Res 2016; 16(1):683.

22. Richard L, Furler J, Densley K, Haggerty J, Russell G, Levesque J-F, Gunn J. Equity of access to primary healthcare for vulnerable populations: the IMPACT international online survey of innovations. Int $J$ Equity Health 2016; 15(1):64.

23. Zwiech R, Bruzda-Zwiech A. Does oral health contribute to post-transplant complications in kidney allograft recipients? Acta Odontol Scand 2013; 71(34):756-763.

24. Klassen JT, Krasko BM. The dental health status of dialysis patients. J Can Dent Assoc 2002; 68(1):34-38.

25. Mattos RA. Comprehensiveness in practice (or, on the practice of comprehensiveness). Cad Saude Publica 2004; 20(5):1411-1416.

26. Kalichman AO, Ayres JR. Comprehensiveness and healthcare technologies: a narrative on conceptual contributions to the construction of the comprehensiveness principle in the Brazilian Unified National Health System. Cad Saude Publica 2016; 32(8):e00183415.
27. Martins RC, Reis CM, Matta Machado AT, Amaral $\mathrm{JH}$, Werneck MA, Abreu MH. Relationship between primary and secondary dental care in public health services in Brazil. PloS One 2016; 11(10):e0164986.

28. Wang T-F, Shi L, Nie X, Zhu J. Race/ethnicity, insurance, income and access to care: the influence of health status. Int J Equity Health 2013; 12(1):29.

29. Haikal DS, Martins AM, Aguiar PH, Silveira MF, Paula AM, Ferreira EF. Access to information on oral hygiene and tooth loss due to caries among adults. Cien Saude Colet 2014; 19(1):287-300.

30. Nunn JH, Sharp J, Lambert HJ, Plant ND, Coulthard MG. Oral health in children with renal disease. Pediatric Nephrol 2000; 14(10-11):997-1001.

31. Tomás I, Marinho J, Limeres J, Santos M, Araújo L, Diz P. Changes in salivary composition in patients with renal failure. Arch Oral Biol 2008; 53(6):528-532.

32. Abdellatif AM, Hegazy SA, Youssef JM. The oral health status and salivary parameters of Egyptian children on haemodialysis. J Adv Res 2011; 2(4):313-318.

33. Ziebolz D, Fischer P, Hornecker E, Mausberg RF. Oral health of hemodialysis patients: A cross-sectional study at two German dialysis centers. Hemodial Int 2012;16(1):69-75.

Article submitted 21/10/2017

Approved 18/06/2018

Final version submitted 20/06/2018 